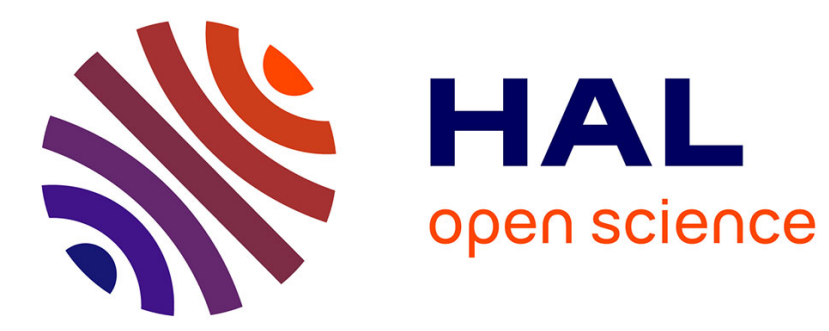

\title{
Responsible Global Humanism as a New Model for Business Schools
}

Carlos Rabasso, Javier Rabasso

\section{To cite this version:}

Carlos Rabasso, Javier Rabasso. Responsible Global Humanism as a New Model for Business Schools. Athens Journal of Business \& Economics, 2015, 1 (2), pp.123-134. 10.30958/ajbe.1-2-3 . hal02478204

\section{HAL Id: hal-02478204}

\section{https://hal-normandie-univ.archives-ouvertes.fr/hal-02478204}

Submitted on 13 Jul 2021

HAL is a multi-disciplinary open access archive for the deposit and dissemination of scientific research documents, whether they are published or not. The documents may come from teaching and research institutions in France or abroad, or from public or private research centers.
L'archive ouverte pluridisciplinaire HAL, est destinée au dépôt et à la diffusion de documents scientifiques de niveau recherche, publiés ou non, émanant des établissements d'enseignement et de recherche français ou étrangers, des laboratoires publics ou privés.

\section{다)(1) $(5$}

Distributed under a Creative Commons Attribution - NonCommerciall 4.0 International 


\title{
Responsible Global Humanism as a New Model for Business Schools
}

\author{
By Carlos Rabasso* \\ Javier Rabasso ${ }^{\dagger}$
}

\begin{abstract}
This paper examines the elements that make up global humanist learning (GHL) about cross-cultural management education (CCME) for the training of international responsible future managers. The first part of this study shows how business schools can find their way implementing a new curriculum based on transversal humanist studies and global responsibility. The study shows how, besides her/his cross-cultural knowledge, the future executive has to show a great adaptability acquired through a slow training characterised by cultural diversity with a global humanistic (human and social sciences) background coming from different cultures and perspectives. The second part of this paper develops the notion of sustainable education for responsible transcultural managers. Well-being is at the core of this section giving special importance to the notion of sustainable happiness in the workplace, element that replaces the sacro-saint three " $P$ " concepts in traditional business: productivity, performance and profitability. The paper highlights new values in an emerging responsible "green environment" such as caring, "maternalistic" management, integral thinking and love for humanity in playful enjoyable contexts. The third part of this paper underlines the importance of a global humanism which questions Eurocentric and Western thinking as the main ground theory for business education. The paper will put forward the necessity of a post-colonial approach from political, social, economic and cultural thinkers and activists from emerging environments. Finally, this work will propose new challenges for the future: a profile for another kind of responsible business school across the globe.
\end{abstract}

\section{Introduction: Changing the Curriculum}

Business schools and universities across the world have been changing their curriculum as our business and financial environments become more responsible and transparent as a result of the continuous crisis emerged from bad and irresponsible practices. The new challenges for responsible leaders

\footnotetext{
*Associate Professor, Neoma Business School, France.

†Maître de Conférence, Université de Rouen, France.
} 
towards the creation of a more sustainable planet are also present in the training of future managers. As a result there has been an increasing interest in how business education can incorporate in their courses and seminars social and human sciences as a way to embrace systemic and holistic education as the new way for learning and teaching. This implies the creation of interdisciplinary departments and the hiring of teachers from different fields to give the students a transversal perspective about business and the economy. Responsible Global Humanism (RGH) appears then as an alternative way to foresee humanities from a larger scope as the contribution and findings of scholars and practitioners from emerging countries is becoming more relevant for our global economy. The changes that our business schools are experimenting today are the result of the need to learn from silent and dissident voices that can help the business community to better understand the happenings and complexities of our diverse economic, cultural, political, social and economic environments. From this perspective, this paper in divided in three different parts, each of them interconnected as transversal humanism and global responsibility (first part) is intimately related to sustainable practices in education for transcultural managers (second part), and both of them are part of a larger project which embraces global humanism as an extension of postcolonial thinking for critical business education (third part). Many of the concepts and decentred approaches proposed in this article are part of the teachings done by several professors in responsible business schools across the world, like Neoma Business School in France ${ }^{1}$ (former Rouen Business Schools). The objective of this paper is to inspire other colleagues and researchers to apply and incorporate into their education and learning critical responsible business education considering interrelated disciplines as Critical Management, Diversity Management, Cross Cultural Management, Comparative Management, Social Sciences, Cross Cultural Communication, Postcolonial Thinking, Subaltern Studies, Integral Thinking, Sustainability and other interrelated fields.

\section{Transversal Humanist Studies and Global Responsibility for Business Schools}

Transversal Education is a need many universities are considering as specialisation for management studies is becoming less and less relevant (Rabasso \& Rabasso, 2011). Business students across the world are trained to understand and "pilot" corporations without specific technical knowledge as before. Finance and accounting are not any longer indispensable tools for becoming a business leader. The collective intelligence of our learning corporations encourages the creation of interdisciplinary teams with specialist "knowledge" workers and transversal managers coming from very different fields such as engineering, medicine, architecture, physics, fine arts, sociology,

${ }^{1}$ NEOMA Business School was born in September 2013 as the merger of Rouen Business School and Reims Management School in France. 
literature, history, philosophy and so on. Systemic thinking as a way of understanding our business world is a must for the education of future business leaders as creating links and hybrid solutions is part of a more complex "fuzzy" environment where binary oppositions and monolithic views have been replaced by complex and integral approaches to find solutions and new ways to cope with the challenges of sustainability and global responsibility. Transcultural educational business training means the creation of multidisciplinary departments and research projects with a staff coming from different fields and geopolitical backgrounds, as well as culturally diverse milieus, with opposing views about many issues, scholars that will open up the debate and enlarge the scope for alternative and creative solutions and practices. The implementation of critical thinking in many disciplines, questioning traditional and obsolete values in the context of our global world will encourage business educational institutions for radical changes in their vision and in the "genetic" cultural print of the corporate world.

Humanist management has been a recent topic developed by management journals like The Journal of Business Ethics in different issues (volume 78 in March 2008; volume 88 in September 2009; volume 99 in March 2011). Some top universities in United States and in Great Britain recently created Humanist Master of Business Administration as the incorporation of humanities becomes crucial for the training of professional business leaders. For many scholars humanism "is usually conceived as an outlook emphasizing common human needs and is concerned with human characteristics" (Melé 2003, 78). From this perspective the term humanism is related to several approaches when referred to humanistic management: the human motivation (Anderson, 1997), the organizational culture (Peus and Frey, 2009) and the business as a community of persons embedded with an organizational culture which fosters character (Melé, Argadona \& Sanchez-Runde, 2011). It is important to understand the relationship and the tension created between the values fostered by national cultures, corporate cultures and professional cultures, as the principles and objectives of Nation-States cultures towards their citizens many times collide with the economic interests of corporations and the vision of professionals through their actions and accomplishments. A new global humanist perspective incorporated into business education has to take into account the emerging of an interconnected environment where the needs of the most do not reflect mostly the interest of the few. Global responsibility comes into play when most is need today, in the managing of transnational corporations which elude public interest as the prime goal of their activities is pure economic profit. This is the case of top global brands in specific sectors as technology where most of its business practices try to avoid paying taxes and giving fair wages to their employees (Amazon, Google, Facebook and so on).

Global humanism is closely related to global thinking as responsible leaders will understand the problems and solutions with complex ways of dealing with specific subjects and people. As a result, the business environment is looking for new ways to develop responsible global actions. The founding 
principle for the Globally Responsible Leadership Initiative (GRLI) ${ }^{1}$ has been for the last fifteen years, "Think Big, Act Small, and Start Now". Like many other global responsible organizations, the GRLI engaged business educational institutions and corporations for better managing our planet. This organization participated few years after the publication of the Global Compact principles by the United Nations launched in 2000, in the elaboration of the 8 Principles for Responsible Management Education (2007), with more than 3000 companies from 100 countries, as well as over 700 hundred civil organizations which included many educational institutions. These principles are the founding ground for global action towards a more responsible planet. Most of them highlight the importance of sustainability, responsible learning, the interconnection between the teachings in business educational institutions and the "green" and responsible practices of the corporate world and so on. For this purpose educational business organizations and universities participated in the discussion and elaboration of these principles which engaged all the participants $^{2}$. Global responsibility is a concept that enriches corporate social responsibility towards a more sustainable and culturally diverse environment. The 10 principles of the Global Compact are related to Human Rights, Labour, Environment and Anti-Corruption. These are new fields business educational institutions incorporate in their courses studying how to avoid the bad practices of corporations in relation to the Global Compact principles. Global Humanism, as a consequence, highlights the importance of non-profit organizations all over the world (for instance, the Green Belt Movement in Africa $^{3}$, The Barefoot College ${ }^{4}$ and the Self-Employed Women Association in India $^{5}$, Gawad Kalinga ${ }^{1}$ in the Philippines, Comunalidad ${ }^{2}$ in native Latin

\footnotetext{
${ }^{1}$ The Globally Responsible Leaders Initiative (GRLI) was co-founded and is supported by the United Nations Global Compact and the European Foundation for Management Development (EFMD). The GRLI's mission is to act as a catalyst to develop a next generation of globally responsible leaders.

${ }^{2}$ Among others it is important to mention the contribution of AACSB International; EFMD; The Aspen Institute's Business and Society Program; Globally Responsible Leadership Initiative; ESSEC Business School, France; INSEAD, France; Tecnológico de Monterrey, Mexico; Harvard Business School, USA; China Europe International Business School, China; Getulio Vargas Foundation, Brazil; Universidad de los Andes, Colombia; Yale School of Management, USA; Queen's School of Business, Canada; Indian Institute of Management, Bangalore, India; Norwegian School of Management, Norway; Moscow School of Management-Skolkovo, Russia; Bina Nusantara University, Indonesia; Middle East Technical University, Turkey; ESADE Business School, Spain; Columbia University, USA; Keio University, Japan and many others.

${ }^{3}$ The Green Belt Movement (GBM) is an indigenous grassroots non-governmental organization based in Nairobi, Kenya that takes a holistic approach to development by focusing on environmental conservation, community development and capacity building. Professor Wangari Maathai established the organization in 1977, under the auspices of the National Council of Women of Kenya.

${ }^{4}$ Barefoot College is a voluntary organization working in the fields of education, skill development, health, drinking water, women empowerment and electrification through solar power for the upliftment of rural people, which was founded by Bunker Roy in 1972.

${ }^{5}$ The Self-Employed Women's Association of India (SEWA) is a trade union for poor, selfemployed women workers in India. SEWA was founded in 1972 by the noted Gandhian and civil rights leader Dr. Ela Bhatt.
} 
America and so on) as well as committed activists, thinkers, economists and managers like Vandana Shiva, Joseph Stiglitz, Amartya Sen, Wangari Maathai, Bunker Roy, John Zerzan, Fritjof Capra, Andrew Dowson, Paul Hawken, Ricardo Semler and so on.

Business environments are looking for creative ways to develop sustainable practice and responsible behaviour among their participants. A new humanistic vision is need it (Melé, Argandona and Sanchez-Runde, 2011) after the latest global financial practices initiated in Western countries, cultures where the European Enlightenment of the late XVIIIth century envisioned the construction of a better world thanks to technology, Modernity and Progress. Our global environments need a new foundation to build future sustainable businesses that will be able to deal with the world human needs (Acevedo, 2012; Pirson and Turnbull, 2011; Spitzeck, 2011). Responsible leaders across the planet should be perceived as ethical and caring managers with moral sensitivity (Whetstone, 2003). Global humanist management enlarges the concept of culture towards visible minorities and silent voices that with the emergence of internet can participate actively with their views, understandings and creative solutions for the construction of a "green" and responsible planet. As a result, global humanism renders human beings more truly human as everyone can participate actively with their talents and virtuosities (Maritain, 1996, 153), to seek for a state of mind that will value the "human wellbeing" (Dierksmeier and Pirson, 2009; Llano et al., 1992; Sison, 2007, 2008). This requires a more holistic vision of business and management that is closely related to sustainability (Melé, Argadona \& Sanchez-Runde, 2011).

Finally, transcultural educational business training means the creation of multidisciplinary departments and research projects with a staff coming from different fields and geopolitical backgrounds, as well as culturally diverse milieus, with opposing views about many issues, scholars that will open up the debate and enlarge the scope for alternative and creative solutions and practices. The implementation of critical thinking in many disciplines, questioning traditional and obsolete values in the context of our global world will encourage business educational institutions for radical changes in their vision and in the "genetic" cultural print of the corporate world.

\footnotetext{
${ }^{1}$ Gawad Kalinga (GK), which means to "give care" in Filipino, is officially known as the Gawad Kalinga Community Development Foundation, a Philippine-based poverty alleviation poverty and nation-building movement. Its mission is to end poverty for 5 million families by 2024.

${ }^{2}$ Comunalidad emerges as a tacit display of social movements in Latin America, which in the 1980s achieved their goal of controlling their own development by conceptualizing their actions.
} 


\section{Sustainable Education for Responsible Transcultural Managers}

How can education be sustainable in a world where practical matters undermine the power of humanities? What is the meaning of "tranculturality"1 applied to management and responsible leadership? Since the emergence of Modernity a city culture has been giving so much importance to Western art and sciences, literature, philosophy, history, social sciences and so on. The history of all this disciplines from a global perspective, including the contribution of non-Western cultures has not been written yet. If we look at most Nobel prizes of literature, more than $90 \%$ come from Western languages in a world with almost 6000 languages spoken and many of them written, with their own writers, thinkers, artists and scientists. The very narrow minded view of culture is the result of an anthropocentric, Eurocentric, logocentric, patriarchal and colonialist understanding of this matter. Sustainable education opens up the debate about dissident and alternative voices coming from emerging countries and minority groups that have been oppressed and indoctrinated by Western education.

Eco literacy is today a very important resource for sustainable education as many ethnic communities are highly developed in biodiversity, natural medicine, storytelling, spiritual learning, arts and crafts for chasing, hunting and self-efficiency, ethical and spiritual values and so on. Education for Sustainable Development (ESD) has been used by the United Nations in Agenda 21, support interdisciplinary thinking and the growing importance of systems thinking as the complexities of our environment demand people from all sort of disciplines and fields to solve the problems and the envisage the future. Following Tilbury, D. and Wortman, D. (2004), sustainable education is based on several skills: 1. Envisioning a better future; 2 . Critical Thinking to analyse and question the economic, environmental, social and cultural aspects that conform our global environment; 3. Networking based on dialogue and negotiation among cultures. The United Nations declared 2005-2014 the UN Decade of Education for Sustainable Development (DESD), as the main task is to develop a vision towards sustainable development all over the world with many educational organisations supporting it $^{2}$.

Critical thinking has been a very useful tool to question the alienating environments people have been trapped in through the consumption of brands and the use of digital technologies, as well as being bombarded with commercials of all sorts placed through mass media and advertisement ready to

\footnotetext{
${ }^{1}$ This concept was created by a Cuban anthropologist, Fernando Ortiz, in an essay published in Spanish, Contrapunteo cubano entre del Tabaco y del azúcar (1940). This concept anticipates postcolonial thinking as it claims a dialogical collective imagination (Bahktin) in the processes of globalization with a great variety of differentiation and cultural diversity.

${ }^{2}$ Among others, it is worth to mention the Green Education Foundation (GEF), London South Bank University with a Master's program in Education for Sustainability, the Centre for Environment Education in Ahmedabad, India, the Swedish International Centre of Education for Sustainable Development (SWEDESD), Mount Allison University and St. John International University.
} 
invade people's minds and condition their buying behaviour. A sustainable life has become a must to save citizens from consumerism as an ideal way of acquiring happiness based on material things which are the consequence of manufacturing products from raw materials overused from a damage environment. Our planet is sick because over production and consumption. A sustainable world is a real need to save it. Simple living ${ }^{1}$ becomes, therefore, a way to encourage individuals to downsize their belongings and downshift their over worked and consumption schedule. Sustainability claims for a less consumptive society with many voluntary ways to simplify one's lifestyle reducing the amount of material things as people will be satisfied with what they need rather than want. A responsible transcultural manager has to understand that quality of life demands from corporations questioning mass production to create better products and services for a planet that will understand luxury as related to the inner value of the things and the activities people do and have through time, as the world of obsolescence is already an obsolete concept. Lasting becomes, in a sustainable environment, an added value for the products, services and networking relationships people will develop through their lifetime. For this purpose, quality time, work-life balance, personal taste and opinions away from standard views, frugality and slowness, reducing the personal ecological footprint, de-growth, ethnic diversity, pacifism, primitivism, ecology and a total rejection of conspicuous consumption are different aspects of sustainable education for responsible leaders trained to manage the planet and not only serving the private interest of the corporate world.

To accomplish this, sustainable education has to look back and learn from the history of responsible actions and movements through history across cultures, from the Sharamana ${ }^{2}$ traditions in Iron Age India to the Amish simple living practices in United States, as well as individuals inspired by ascetic practices like Francis of Assisi, Rabindranath Tagore and Mohandas Gandhi. A Global Humanist perspective into business education will take into consideration the teachings of Confucius, Mohammed, Zarathustra, Buddha as well as Judeo-Christian ethics and Greco-Latin culture and philosophy. There has been an increasing grassroot awareness in recent years with the creation of the National Downshifting Week in United Kingdom since 1995 which encourages "Slow Down and Green Up", giving many suggestions for individuals and corporations, as well as educational institutions to adopt green policies and habits to create environmental and corporate responsibility. Some radical thinkers like John Zerzan (Against Civilisation, 2005) and Tom Hodgkinson (How to Be Free, 2006) encourage people not to consume to be self-sufficient and start producing at home fruits and vegetables for instance.

\footnotetext{
${ }^{1}$ Simple Living encompasses a number of different voluntary practices to simplify one's life style.

${ }^{2}$ Sharamana was a non-Vedic Indian religious movement parallel to but separate from the historical Vedic religion. Several śramana movements are known to have existed in India, even before the 6th century BCE, and these influenced both the Astika and the Nastika traditions of Indian philosophy.
} 
Sustainable education encourages the consumption of local products (also highlighted by the Slow Food Movement ${ }^{1}$ ) with the idea of food miles, as well as producing films and literature online (Annie Leonard's ecological videos is the best example $)^{2}$. Green politics and deep ecology are part of this new "simple" trend ${ }^{3}$ against mass consumption and pathological growth, claiming like David Wann for "simple prosperity" (2007) as the preservation of public space in cities and natural environments for the benefit of a collective Dionysian intelligence where man and nature will exchange a creative and spiritual dialogue for the benefit of the planet.

Sustainable education has to consider the basic founding principles of many spiritual movements that are part of the foundations of our "green" responsible environments today. The Taoist principle "Wu wei" 4 is at the core of this radical ecological view, a very important concept in the Tao te Ching written by Laozi. It explains how we have to live and behave in harmony with the universe without effort, accepting ourselves for who we are. Becoming or projecting our lives into the future, as Modernity and European Humanism claimed through history, is not the purpose of our existence but living the present, living it within and not fighting, arguing, opposing or changing Nature so people will not alter the harmony already existing in our environments. This is a very conservative and sustainable principle which claims the Mozi Universal Love principle (Jian ài) ${ }^{5}$ and goes against the "episteme" of Modern Times where progress is always looking for newness and originality. The Indian natural concept of "Sahaja" practiced in yoga is also related to sustainable practices as encourages its practitioners to be in conformity through a state of freedom and peace with the Natural Law of the Universe.

As a result, sustainable education opens up the debate about dissident and alternative voices coming from emerging countries and minority groups that have been oppressed and indoctrinated by Western education. For this purpose, quality time, work-life balance, personal taste and opinions away from standard views, frugality and slowness, reducing the personal ecological footprint, degrowth, ethnic diversity, pacifism, primitivism, ecology and a total rejection of

\footnotetext{
${ }^{1}$ Slow Food is an international movement founded by Carlos Petrini in 1986. Promoted as an alternative to fast food, it strives to preserve traditional and regional cuisine and encourages farming of plants, seeds and livestock characteristic of the local ecosystem.

${ }^{2}$ http://storyofstuff.org/

${ }^{3}$ Duane Elgin, Voluntary Simplicity, New York: Harper, 2010.

${ }^{4} \mathrm{Wu}$ wei is an important concept in Taoism that literally means non-action or non-doing.

${ }^{5}$ Mozi (470 BC - 391 BC) was a Chinese philosopher during the Hundred Schoools of Thought Hundred period (early Warring States period) .Mozi Universal Love principle (Jian ài) tried to replace what he considered to be the long-entrenched Chinese over-attachment to family and clan structures with the concept of "impartial caring" or "universal love" ( jiān ài). In this, he argued directly against Confucians who had argued that it was natural and correct for people to care about different people in different degrees. Mozi, in contrast, argued that people in principle should care for all people equally, a notion that philosophers in other schools found absurd, as they interpreted this notion as implying no special amount of care or duty towards one's parents and family.

${ }^{6}$ Sahaja means spontaneous, natural, simple or easy. It is a term in Indian spirituality and influenced by the Tantric Movement.
} 
conspicuous consumption are different aspects of sustainable education for responsible leaders trained to manage the planet and not only serving the private interest of the corporate world.

\section{Global Humanism and Postcolonial Thinking for Business Education}

A different set of values is necessary today to give our business communities and its participants the spiritual needs our Western civilisation and our global environments are undermining through relentless consumption and violent ways of exploiting people and natural resources. These values question the very essence of our Modern economy, the notions of economic growth and individual profit putting forward the importance of concepts like well-being and Gross National Happiness ${ }^{1}$ as working tools for a more sustainable environment. Postcolonial thinkers can help the business community and our educational management institutions to confront, discuss and try to resolve the problems caused by the abuse and irresponsible patriarchal and self-centered behaviour of Western brands. Many of these thinkers are embracing a maternalistic and caring concern about the economic in relation to other aspects of everyday life. Global humanism as a result dialogues with the ethics of care and feminist theory as a way to come to a universal pattern of responsible behaviour through corporations and individuals engaged in sustainability. Female scholars since the nineteen eighties like Carol Gilligan (1982) and Nel Noddings (1984) established a very fruitful dialogue on caring with dissident postcolonial thinkers coming from emerging countries since the nineteen seventies like Chandra Talpade Mohanty (2003), Homi K. Bhabha (1994), Achille Mbembé (2001), Roberto Fernández Retamar (2002), Arjun Appadurai (1996), Gayatri Chakravorty Spivak (1988) and Dipesh Chakrabarty (2000). All of them question domination in a growing "hybrid" environment of different cultures in permanent dialogue towards global responsibility, solidarity, caring and sustainable practices.

Global humanism is slowly becoming an important part of the curriculum in business education as a kind of subaltern or peripheral way of learning about sustainability and corporate social responsibility. For this purpose systemic and emotional thinking are ways to decentre colonialist and mechanical (Cartesian and structured) education incorporating intuitive, collective and feminine approaches to education to break down binary oppositions as the base of Eurocentric education. The importance of the irrational, the invisible field, the sacred and the spiritual are elements take into consideration for global humanism as tools or heuristic devices to embrace wisdom through sustainability. From this perspective the voice of subaltern business education

\footnotetext{
${ }^{1}$ Gross National Happiness (GNH) is an indicator created in Bhutan in 1972. It was designed in an attempt to define an indicator and concept that measures quality of life or social progress in more holistic and psychological terms than only the economic indicator of gross domestic product (GDP). GNH has only been officially used in Bhutan, where a Gross National Happiness Commission is charged reviewing policy decisions and allocation of resources.
} 
becomes global as humanism has been overpowered by Western thinkers and scholars undermining the contributions of other cultures, languages and identities. Modernization mainstream theory based in business education on the teachings of free trade, open markers, individual profit, representative democracy and capitalist economy becomes less important in the learning process of business students as postcolonial thinking questions the pre-existing condition of a superior culture base on Western values (Lawson, 2007). Global Humanism speaks from the silent voices that did not participated in the social, cultural, political and economic process as they were not considered subjects of history such as ethnic minorities, woman, challenge people, subordinated or colonized cultures and children. As a consequence, critical thinking will be an indispensable tool for this matter, playing with binary oppositions and negotiating contradictory views in a fuzzy and a hybrid way of learning the questioning and not the answering, embracing confusion and chaos as well as entropy, disorder and ambiguity, dealing with opposite solutions and accepting paradox and irrational understanding as a feminine way to confront complex realities (Rabasso \& Rabasso, 2010). Global humanism dialogues with the founding texts of postcolonial theory such as the works of Aimé Césaire (1955, published in English in 2000), Frantz Fanon (1952, published in English 1967; 1961, published in English in 1963), Albert Memmi (1957, published in English in 1965), Kwame Nkrumah (1970) and Edward Said (1978). Critical theory finally established connections with a "maternalistic" way of understanding business and the management of organizations (Sanford, 1998) through love and caring for people and the environment. Self-responsibility, trust, interdependency, encouragement, collective responses, positive criticism and transversal thinking are part of the business educational learning as corporations are part of a living organism interconnected and changeable as all its participants are co-creators of a Cosmos which requires sustainability for its own survival.

In conclusion, Global humanism is slowly becoming an important part of the curriculum in business education as a kind of subaltern or peripheral way of learning about sustainability and corporate social responsibility. Global Humanism speaks from the silent voices that did not participated in the social, cultural, political and economic process as they were not considered subjects of history such as ethnic minorities, woman, challenge people, subordinated or colonized cultures and children. 


\section{Steps to become a Responsible Transcultural Manager}

\begin{tabular}{|c|c|c|}
\hline Understanding & Responsible & Humanism......... \\
\hline Curriculum & Business & ......Transversal \\
\hline Studies... & Sustainable & Education............. \\
\hline
\end{tabular}

\section{References}

Acevedo, A. 2012. Personalist Business Ethics and Humanistic Management Insight from Jacques Maritain. Journal of Business Ethics. 105:197-219.

Anderson, C. 1997. Values-based management. Academy of Management Executive. 11(4): 25-46.

Appadurai, A. 1996. Modernity at Large: Cultural Dimensions of Globalization. University of Minnesota Press, Minneapolis.

Bhabha, H. K. 1994. The Location of Culture. Routledge, New York

Césaire, A. 2000. Discourse on Colonialism. Monthly Review Press, New York.

Chakrabarty, D. 2000. Habitations of Modernity: Essays in the Wake of Subaltern Studies. University of Chicago Press, Chicago.

Dierksmeier, C. and Pirson, M. 2009. Oikonomia Versus Chrematistike: Learning from Aristotle About the Future Orientation of Business Management. Journal of Business Ethics. 88(3):417-430.

Fanon, F. 1967. Black Skin, White Mask. Grove Press, New York.

Fanon, F 1963. The Wretched of the Earth. Grove Weidenfeld, New York.

Fernández Retamar, R. 2002. Todo Calibán. Ediciones Callejón, San Juan, Puerto Rico.

Gilligan, C. 1982. In a Different Voice. Harvard University Press, Boston, MA.

Lawson, V. 2007. Making Development Geography. Routledge, New York.

Hodgkinson, T. 2006. How to Be Free. Penguin Books, London.

Llano, A., Alvira, R., Calleja, T., Bastons, M., Martinez Esteruelas, C. 1992. El humanismo en la empresa. Rialp, Madrid.

Maritain, J. 1936/1996. Integral Humanism. In O. Bird (Ed.), Integral humanism, freedom in the modern world, and a letter on independence.143-345. University of Notre Dame Press, Notre Dame.

Mbembe, A. 2001. On the Postcolony. University of California Press, Berkeley, CA

Memmi, A. 1965. The Colonizer and the Colonized. Beacon Press, Boston.

Melé, D. 2003. The challenge of humanistic management. Journal of Business Ethics. 44(1): 77-88.

Melé, D., Argandona, A., \& Sanchez-Runde, C. 2011. Facing the Crisis : Towards a New Humanistic Synthesis for Business. Journal of Business Ethics. 99 (1): 1-4.

Mohanty, C. T. 2003. Feminism without Borders: Decolonizing Theory, Practicing Solidarity. Duke University Press Books, Durham, NC.

Nkrumah, K. 1970. Consciencism: philosophy and ideology for de-colonization. New York: Monthly Review Press, New York.

Nodding, N. 1984. Caring: A Feminine Approach to Ethics and Moral Education. University of California Press, Berkeley, CA.

Ortiz, F. 2002. Contrapunteo cubano del tabaco y del azúcar. Cátedra, Madrid.

Peus, C., Frey, D. 2009. Humanism at work: Crucial organizational cultures and leadership principles. Humanism in Business. 260-298. 
Pirson, M., Turnbull, S. 2011. Towards a more humanistic governance model: Network governance structures. Journal of Business Ethics. 99 (1): 101-114.

Rabassó, C. and Rabassó, J. 2010, A Chomskyan Approach to Responsible Critical Management Education, Journal of Global Responsibility. Vol. $1 \mathrm{~N}^{\circ} 1$, pp.66-84.

Rabassó, C. and Rabassó, J. 2011. Educating Responsible Transcultural Managers for Open Environments and Organisations, International Journal of Employment Studies. Vol.19 N², pp. 33-61.

Said, E. 1978. Orientalism. Vintage Books, New York.

Sanford, K. D. 1998. Leading With Love: How Women (and Men) Can Transform Their Organizations Through Maternalistic Management. Vashon Publishing, Seattle.

Sison, A. J. G. 2007. Toward a Common Good Theory of the Firm: The Tasubinsa Case. Journal of Business Ethics. 74 (4): 471-480.

Sison, A. J. G. 2008. Corporate Governance and Ethics: An Aristotelian Perspective. Edward Elgar, Cheltenham, UK.

Spitzeck, H. 2011. An Integrated Model of Humanistic Management. Journal of Business Ethics. 99 (1): 51-62.

Spivak, G. C. 1988. Can the Subaltern Speak?. Marxism and the Interpretation of Culture. Ed. Cary Nelson and Lawrence Grossberg. University of Illinois Press, 271-313.

Spivak, G. C. 2003. Death of a Discipline, Columbia University Press, New York.

Tilbury, D. and Wortman, D. 2004. Engaging People in Sustainability. IUCN, Gland, Switzerland and Cambridge.

Wann, D. 2007. Simple Prosperity: Finding Real Wealth in a Sustainable Lifestyle. St. Martin's Griffin, New York.

Whetstone, J. T. 2003. The language of managerial excellence: Virtues as understood and applied". Journal of Business Ethics. 44 (4): 343-357.

Zerzan, J., ed. 2005. Against Civilisation. Port Townsend, Feral House, Port Townsend, WA. 